\title{
A Theoretical Study on the Empowerment of Women in Bangladesh: Social, Legal, and Economical Perspective
}

\author{
Antora Goswami ${ }^{1}$ \& Sunjida Islam ${ }^{2}$ \\ ${ }^{1}$ Lecturer, Department of Sociology, Rajshahi Science \& Technology University, \\ Natore, Rajshahi, Bangladesh \\ ${ }^{2}$ Assistant Professor, Department of Law, Rajshahi Science \& Technology University, \\ Natore, Rajshahi, Bangladesh \\ Corresponding author E-mail: antoragoswamiru@gmail.com
}

Area/Section: Social Science.

Type of the Paper: Research Paper.

Type of Review: Peer Reviewed.

Indexed in: OpenAIRE.

DOI: http://doi.org/10.5281/zenodo.3545147.

Google Scholar Citation: IJMTS

\section{How to Cite this Paper:}

Goswami, Antora \& Islam, Sunjida. (2019). A Theoretical Study on the Empowerment of Women in Bangladesh: Social, Legal, and Economical Perspective. International Journal of Management, Technology, and Social Sciences (IJMTS), 4(2), 69-73.

DOI:http://doi.org/10.5281/zenodo.3545147.

International Journal of Management, Technology, and Social Sciences (IJMTS) A Refereed International Journal of Srinivas University, India.

IFSIJ Journal Impact Factor for $2018=4.764$

(C) With Author.

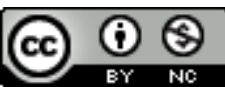

This work is licensed under a Creative Commons Attribution-Non Commercial 4.0 International License subject to proper citation to the publication source of the work.

Disclaimer: The scholarly papers as reviewed and published by the Srinivas Publications (S.P.), India are the views and opinions of their respective authors and are not the views or opinions of the SP. The SP disclaims of any harm or loss caused due to the published content to any party. 


\title{
A Theoretical Study on the Empowerment of Women in Bangladesh: Social, Legal, and Economical Perspective
}

\author{
Antora Goswami ${ }^{1}$ \& Sunjida Islam $^{2}$ \\ ${ }^{1}$ Lecturer, Department of Sociology, Rajshahi Science \& Technology University, \\ Natore, Rajshahi, Bangladesh \\ ${ }^{2}$ Assistant Professor, Department of Law, Rajshahi Science \& Technology University, \\ Natore, Rajshahi, Bangladesh \\ Corresponding author: E-mail: antoragoswamiru@gmail.com
}

\begin{abstract}
Bangladesh is a developing country and most of the people of this country is a woman. The social and economic conditions of the women in here are not good and complex as well. They are struggling every moment to keep their position settle in the family and in the society by overcoming different embodiments and multilateral pressures. Equal participation of men and women in any uplift activities in the society is not facile here. Many operations taken by women are not considered as work in society. Now-a-days women are working in different sectors such as administrative sectors, judicial sectors, medical sectors and other sectors which are not safe for them but they can't their proper respect and status. Moreover, they are often neglected, tortured and persecuted in their family and society. It is a devaluation and this devaluation hinders the rights of women. And that's why women can't stay parallel with men and can't enjoy equal right to overcome gender disparity. But the better news is that recently women are raising their voice in favour of their rights. This article provides the importance of women empowerment, how the dignity of women can increase, what types of roles are fulfilled by the women as well as how they overcome the obstacles behind the development.
\end{abstract}

Keywords: Empowerment, Women, Development, Society, Parallel, Dignity.

\section{INTRODUCTION :}

Disempowerment of women based on various reasons is a stain on human civilization. Due to low status of women approximately half of Bangladeshi population is left behind in darkness. Most of the women can't come out outside the home and they are always struggling with their home traditional roles. They can't work according to their own choice. Although some women can do so but their power, position and earning are limited and lower than men. The experience is mainly rooted in the failure to value women for anything but their reproductive role. In Bangladesh women are affecting through different ways like illiteracy, force labour, low life expectancy, no equal ownership of land, unemployment, high fertility, mortality, etc. They are always facing legal ignorance, social oppression, political exploitation and technological deprivation. In aword, in almost all the spheres of their life they are tortured and neglected by the men empowered society.On the ground of this cruel scenario, the empowerment of women in Bangladesh is very important and necessary now [1].

\section{ANALYSIS OF LATEST RESEARCH WHERE THE SOLUTION OF THE PROBLEM WAS INITIATED :}

Preparing a Research work or an Article successfully \& scientifically, the literature review is very important. To write and complete this article, law books, law journals, and other media has been pursued. Mosedale, Sarah (2005)[1] provides some information to understand what is women empowerment and how women are encouraged to work outsides. Women in Bangladesh are in backward position in the case of employment. They are facing 
many problems in the working place. In Bangladesh, the research of the discussed subject is conducted by such writers and researchers as Ellis, Amanda (2007) [2], Nussbaum, Martha C. (1995) [3]. They are discussing the social consequences of women empowerment, present situation of women empowerment in Bangladesh, lack of the present laws of Bangladesh regarding women empowerment and how to improve the power of women in working sectors.

\section{AIMS OF PAPER\&METHODS :}

This research work is a library-based and theoretical work. Every social and scientific research work has some specific aims and objectives. The main aim of this paper is to focus women empowerment in Bangladesh. In Bangladesh, women are facing different types of critical problems to involve themselves in any work. They also face some social and family embargo in the case of employment. The Government of Bangladesh is continuously trying to find out the basic reasons behind this and trying to resolve the problems. The important objective of this paper is to improve the power of women as an employee in different working sectors. It has some other motives also such as new policy-making, changing social outlook, taking measures to removes obstacles and others.

\section{EMPOWERMENT OF WOMEN IN BANGLADESH:}

Foreign Minister A K Abdul Momen said that Bangladesh is becoming a role model of women empowerment in the world as Bangladeshi women are in leadership position at every sphere of national and social life. Describing various measures taken by the govt to ensure holistic empowerment of women, he said Bangladesh govt introduced gender budget which is unique in the world. We are trying to break many glass ceilings by inducting more qualified women in top positions in judiciary, administration, defense and diplomacy: He said, "we are proud of our female peacekeepers who are holding our flag high in many UN peacekeeping missions". The foreign minister was addressing inaugural session of the summit styled "She Rokers MyEO women summit" and "She Rokers MyEO women SDG Award 2019” at Raddisson Blue Dhaka water Garden. Bangladesh chapter Entrepreneurship Organization (EO), the world's largest peer to peer global network of entrepreneurs organized the summit. In terms of political empowerment of women, Foreign Minister Momen said that Bangladesh is one of the few countries of the world that has women as prime minister, parliament speaker and cabinet ministers. The number of working women has increased to 18.6 million in 2016-2017 from 16.2 million in 2010. Foreign Minister Momen said "we have 57 percent of our women engaged in the work force, with 80 percent forming the backbone of our readymade garment sectors and female migrant workers are contributing to our economy by bringing in remittance" he added. Global chairperson of Entrepreneurship Organization (EO) Babu Andres said the countries women are helping to keep Bangladesh on the right path of development. President of EO Bangladesh chapter Farzana Chowdhury said "No change is possible without inclusion of women adding She Rokers is an initiative for honouring and inspiring entrepreneurship." At the end of the summit, EO Bangladesh chapter conferred awards on 21 Bangladeshi women entrepreneurs in recognition of their contributions to achieve SDG-5 which targets gender equality, said a press release [4].

\section{SOCIAL CONSEQUENCES OF WOMEN'S EMPLOYMENT IN MODERN SOCIETY:}

women are found in a large number in the work force today. The great industrial revolution and the consequent industrialization opened the doors of employment for women. Women started availing themselves of the employment opportunities in almost all the civilized countries including Bangladesh. Adult women no longer associated solely with the role of 'homemaker' specially in the urban areas. Millions of women married and single with and without children are working outside home. A greater proportion of women are seeking and obtaining paid employment more than ever before. In America 
for example, more than $55 \%$ of adult American women held jobs outside the home as compared with only $43 \%$ in 1970 . In Bangladesh also the percentage of employed women is steadily increasing specially in the urban area. Provision of employment opportunities for women on wage, salary or other type of remuneration basis outside the family has been a socio-economic development of great importance. Women's increasing involvement in paid labor force has led to a number of social consequences of which the following may be noted. In modern societies women are engaged in a job outside the family and obtaining good salary or income are more respected than women without a gainful job. As far as women are concerned their self-esteem and power within the family too should increase as they move outside the home and function as productive wage-earners. Employment of women outside the home helps them become more confident and courageous. It gives scope for them to become career-conscious and inspires them to make accomplishment independent of family roles. It widens their vision and broadens their field of work. Women have now started their search for prestigious positions and occupations. Even though the number of women employed in high prestigejobs is comparatively less, their overall selfesteem as working women, has increased [5].

\section{OBSTACLES OF EMPOWERMENT OF WOMEN IN BANGLADESH:}

The factors behind the disempowerment of women are a legion. However, we can drive the major factors into three categories. (i) Economic factors, (ii) Socio-cultural factors, (iii) Political factors :

Economic factors: Due to their non-wage economic activities majority of the women are economically dependent on men from childhood to older ages, Women depend on men in various ways in Bangladesh. Such dependence on men is mainly responsible for their disempowerment. The land owned by a household is mainly owned by a man and women are deprived of this right. Women's landlessness reduced women's power in the household even for wealthy women [5].

Socio-cultural and religious factors: Most of the women of Bangladesh are illiterate. The rate of illiteracy of women is more less than that of men. In the traditional society of Bangladesh, women are socially ignored. They are considered as a burden for their family. So, people generally do not tend to welcome a girl in their family.

Political factors: Our political parties are not fond of making room for women in their party politics. Although both the government and opposition parties are headed by two women, women's representation in party committees and other bodies is very minimal. The participation of women in electoral politics is insignificant. It is mainly due to male control of party organization, women lack of access to the kind of money and patronage, the aggressive electioneering tactics etc.

\section{RECOMMENDATIONS :}

1. To develop their rights women should perform different types indoor and outdoor activities.

2. The social, legal and economic sectors of women working should be extended to overcome the obstacles.

3. Social movements should be increased to change the social sentiment towards women and men.

4. The govt. should enact different laws and take effective actions in favor of women's rights.

5. Government should appoint women equally with men in the higher judicial, administrative, ministerial and other higher departmental post.

6. Government should make reformative and active laws regarding the distribution of wages of men and women to reduce wage disparity.

7. Women should take the help of proper law when they are neglected and persecuted in the job fields by the higher authority.

8. All the national and international treaties in favor of women should be implemented immediately by the govt.

9. We should accept all the activities of women inside or outside the house as 
works and respect all the positive aspects of women for development of society.

10. The govt of Bangladesh should take necessary steps so that women can enjoy equal benefits with men over their father's property.

11. Govt should raise the women consciousness through different activities like seminar, symposium, research work, NGO's programs and other electronic media.

\section{CONCLUSION:}

Twenty first century is ushering in an era of new hopes and aspirations for the women-folk. The women of Bangladesh can now look forward with pride and hope for having some outstanding and significant moments that have taken place in the last three decades for their all-out development. We require both our hands to pray to our creator. So, the active co-operation between men and women a must for real development of a country. In this regard collective efforts by government, NGO and international organization can only accelerate the place of women development and their empowerment in Bangladesh.

\section{REFERENCES:}

[1] Mosedale, S. (2005). Assessing women's empowerment: towards a conceptual framework. Journal of international development, 17(2), 243-257.

[2] Ellis, Amanda. Gender and economic growth in Kenya: Unleashing the power of women. World Bank Publications, 2007.

[3] Nussbaum, Martha C. (1995). Introduction. In Martha C. Nussbaum \& Jonathan Glover (eds.). Women, Culture, and Development: A Study of Human Capabilities. Oxford: Clarendon Press.

[4] The Daily Star News Paper, May 25, 2019.

[5] Richard Schaefer (2009). Sociology. pp. 286287. ISBN - 0073404330. 